\title{
HEPATOPROTECTIVE ACTIVITY OF VERNONIA AMYGDALINA LEAF ETHANOLIC EXTRACT IN WHITE RATS INDUCED BY PARACETAMOL
}

\author{
PANAL SITORUS ${ }^{1}$, NERDY NERDY $^{2 *}$ \\ ${ }^{1}$ Department of Pharmaceutical Biology, Faculty of Pharmacy, Universitas Sumatera Utara, Medan Selayang, Medan Baru, Sumatera Utara, \\ Indonesia. ${ }^{2}$ Department of Pharmaceutical Chemistry, Faculty of Pharmacy, Universitas Sumatera Utara, Medan Selayang, Medan Baru, \\ Sumatera Utara, Indonesia. Email: nerdy190690@gmail.com \\ Received: 20 August 2018, Revised and Accepted: 20 September 2018
}

ABSTRACT

Objectives: A study on the hepatoprotective effect of Vernonia amygdalina leaves ethanolic extract on white rats induced by paracetamol was aimed to obtaining scientific data and evidence the hepatoprotective ability of the extract.

Methods: The research was a complete randomized design, using 36 white rats which were divided into 6 groups. The normal control group was given $1 \%$ carboxy methyl cellulose for 7 days and followed by distilled water 8 hours after treatment. The positive control group was given $100 \mathrm{mg}$ curcumin per kg body weight of rats for 7 days and followed by $2.5 \mathrm{~g}$ paracetamol per kg body weight after treatment. The negative control group was given $1 \%$ carboxy methyl cellulose for 7 days and followed by $2.5 \mathrm{~g}$ paracetamol per kg body weight after treatment. The test group was given 50,100 and 200 mg extract per kg body weight of rats for 7 days and followed by $2.5 \mathrm{~g}$ paracetamol per kg body weight after treatment. Blood sampling was carried out 3 times (before treatment, after treatment and after induction).

Results: With doses of 50,100, and 200 mg extract per kg body weight of rats give significant difference on the decrease of Serum Glutamic Oxaloacetic Transaminase (SGOT) and Serum Glutamic Pyruvic Transaminase (SGPT) levels after paracetamol administration.

Conclusions: It can be concluded that Vernonia amygdalina leaves ethanolic extract were potentially hepatoprotective.

Keywords: Hepatoprotective Activity, Vernonia amygdalina, Ethanolic Extract, White Rats, Paracetamol.

(C) 2018 The Authors. Published by Innovare Academic Sciences Pvt Ltd. This is an open access article under the CC BY license (http://creativecommons. org/licenses/by/4. 0/) DOI: http://dx.doi.org/10.22159/ajpcr.2018.v11i10.29881

\section{INTRODUCTION}

Traditional medicine is ingredients or ingredients in the form of plant ingredients, animal ingredients, mineral materials, which have been used for generations based on experience. The use of natural ingredients as traditional medicines began to be developed. This is because people realize that the side effects caused by synthetic drugs are greater than natural drugs, the price is much cheaper than synthetic drugs, and it is easy to obtain [1]. Therefore, traditional medicine is a field that is still much in demand for research. The development of research runs very fast, among others driven by several things such as the need for compounds to overcome various diseases such as cancer, and also very sought after are drug compounds that are hepatoprotective [2].

Hepatoprotective liver protection is a drug compound that has a therapeutic effect, to restore, maintain, and treat damage from liver function. Functional damage diseases include hepatitis, cancer, fatty liver, hepatic insufficiency, liver cirrhosis, heartburn, gallstones, gallbladder inflammation, small amounts of bile sap, jaundice, and so on [3]. Until now, there has been no drug approved as a hepatoprotector, but for medicinal plants that are now marketed as herbal medicine or a mixture of herbs marketed in Indonesia, it has been recognized as a hepatoprotector.

Several phytochemical extracts have been tested for the anticonvulsan [4], antinephrolitiatic [5,6], antibacterial [7,8], antioxidant [8-11], antidiabetic [12], antimalarial [13,14], anticancer [14-16], and antihepatotoxicity [17] activities. Some medicinal plants that have been researched and recognized as hepatoprotective are turmeric and ginger [18]. The three plants are known to contain very high antioxidants, where these antioxidants are needed in counteracting free radicals which is one of the causes of liver damage [19]. In addition to these three plants, there are still many other medicinal plants that are known to have antioxidant compounds, but their hepatoprotective effects have not been scientifically proven, one of which is Vernonia amygdalina.

There are sevreal phytochemical contained in $V$. amygdalina is thought could inhibit the occurrence of oxidative damage to the liver (hepatoprotective). However, scientific evidence about the effectiveness and efficacy of these traditional drugs in protecting liver damage has not been studied, so research needs to be done to examine the effects of extracting these plants on levels of serum glutamic oxaloacetic transaminase (SGOT) and serum glutamic pyruvic transaminase (SGPT), two types of enzymes that are most often associated with liver damage. This study aims to determine the extent to which the leaves of $V$. amygdalina can protect white rats liver from damage caused by paracetamol and obtain data on doses that produce hepatoprotective activity of $V$. amygdalina leaf ethanolic extract, through examination of SGOT and SGPT enzymes.

\section{RESEARCH METHODS}

\section{Preparation of $V$. amygdalina leaf ethanol extract}

The plant material used in this research was identified by Herbarium Medanese, Department of Biology, Faculty of Mathemetics and Natural Sciences, University of Sumatera Utara. The leaves are dried for several days and then blended into powder. Then, the powder is sieved with a 60 mesh powder sieve. V. amygdalina leaf powder obtained was macerated using ethanol. The extract is filtered using cotton and filter paper, and then, the filtrate obtained is collected and evaporated (thickened) using a rotary evaporator equipped with a water bath and vacuum pump. 
Table 1: SGOT activities in white rats' blood before treatment, after treatment, and after induction

\begin{tabular}{lllllll}
\hline Blood sampling time & \multicolumn{2}{l}{ SGOT (U/L) } & & & \\
\cline { 2 - 7 } & Group I & Group II & Group III & Group IV & Group V & Group VI \\
\hline Before treatment & $29.54 \pm 1.45^{\mathrm{A}}$ & $28.11 \pm 0.94^{\mathrm{A}}$ & $28.45 \pm 1.37^{\mathrm{A}}$ & $28.91 \pm 0.99^{\mathrm{A}}$ & $29.14 \pm 1.15^{\mathrm{A}}$ & $28.75 \pm 1.24^{\mathrm{A}}$ \\
After treatment & $28.45 \pm 1.34^{\mathrm{A}}$ & $27.45 \pm 0.94^{\mathrm{A}}$ & $27.94 \pm 1.25^{\mathrm{A}}$ & $29.64 \pm 1.54^{\mathrm{A}}$ & $28.91 \pm 0.91^{\mathrm{A}}$ & $29.50 \pm 1.18^{\mathrm{A}}$ \\
After induction & $29.18 \pm 0.92^{\mathrm{A}}$ & $30.24 \pm 1.64^{\mathrm{A}}$ & $152.94 \pm 7.15^{\mathrm{B}}$ & $94.84 \pm 3.94^{\mathrm{B}}$ & $30.47 \pm 1.54^{\mathrm{A}}$ & $29.36 \pm 0.94^{\mathrm{A}}$ \\
\hline
\end{tabular}

*Normal control Group (I), Positive control Group (II), Negative control Group (III), Test groups (IV, V, and VI). Numbers followed by different superscript letters on the same line showed a significant difference $(\mathrm{p}<0.05)$, SGOT: Serum glutamic oxaloacetic transaminase

Table 2: SGPT activities in white rats' blood before treatment, after treatment, and after induction

\begin{tabular}{|c|c|c|c|c|c|c|}
\hline \multirow[t]{2}{*}{ Blood sampling time } & \multicolumn{6}{|l|}{ SGOT (U/L) } \\
\hline & Group I & Group II & Group III & Group IV & Group V & Group VI \\
\hline Before treatment & $59.54 \pm 2.15^{\mathrm{A}}$ & $58.84 \pm 1.84^{\mathrm{A}}$ & $58.45 \pm 2.67^{\mathrm{A}}$ & $58.45 \pm 2.48^{\mathrm{A}}$ & $59.54 \pm 2.27^{A}$ & $58.47 \pm 2.15^{A}$ \\
\hline After treatment & $58.45 \pm 2.67^{\mathrm{A}}$ & $57.36 \pm 2.08^{\mathrm{A}}$ & $57.44 \pm 2.55^{\mathrm{A}}$ & $59.64 \pm 2.54^{\mathrm{A}}$ & $58.92 \pm 1.92^{\mathrm{A}}$ & $59.75 \pm 2.28^{\mathrm{A}}$ \\
\hline After Induction & $59.28 \pm 2.91^{\mathrm{A}}$ & $60.48 \pm 2.18^{\mathrm{A}}$ & $294.94 \pm 15.46^{\mathrm{D}}$ & $207.51 \pm 10.17^{\mathrm{C}}$ & $132.14 \pm 2.08^{\mathrm{B}}$ & $59.66 \pm 2.24^{A}$ \\
\hline
\end{tabular}

*Normal control Group (I), Positive control Group (II), Negative control Group (III), Test Group (IV, V, and VI). Numbers followed by different superscript letters on the same line showed a significant difference $(\mathrm{p}<0.05)$, SGOT: Serum glutamic oxaloacetic transaminase, SGPT: Serum glutamic pyruvic transaminase

\section{Hepatoprotective activity test}

Furthermore, the crude extract of $V$. amygdalina leaves was given to white mice. $1 \%$ carboxy methyl cellulose (CMC) solution is made by dissolving approximately $1.0 \mathrm{~g}$ of CMC which has been carefully weighed into water to a volume of $100 \mathrm{ml}$. This solution is used as a paracetamol carrier and extract. Making suspensions and setting the dosage of paracetamol suspension in CMC $1 \%$ were made by dissolving a number of grams of paracetamol that had been weighed into CMC 1\% to a predetermined concentration, namely the hepatotoxic dose. The dose of paracetamol was chosen based on the hepatotoxic dose to rats, $2.5 \mathrm{~g}$ of paracetamol per $\mathrm{kg}$ of body weight (Donatus et al., 1983).

Hepatoprotective test was modified from Manohar et al (2014) research method [20]. Hepatoprotective test on rats was done with the approval of the Animal Research Ethics Committee, Department of Biology, Faculty of Mathemetics and Natural Sciences, University of Sumatera Utara. This study was carried out following a completely randomized design, using 36 male white rats divided into six groups. The normal control Group I was given 1\% CMC for 7 days followed by distilled water $8 \mathrm{~h}$ after treatment. The positive control Group II was given $100 \mathrm{mg}$ of curcumin per $\mathrm{kg}$ of body weight for 7 days followed by $2.5 \mathrm{~g}$ of paracetamol per $\mathrm{kg}$ of body weight after treatment. The negative control Group III was given 1\% CMC for 7 days followed by $2.5 \mathrm{~g}$ paracetamol per kg body weight after treatment. The test groups (IV, V, and VI) were given 50, 100, and $200 \mathrm{mg}$ extract per kg of body weight for 7 days followed by $2.5 \mathrm{~g}$ of paracetamol per $\mathrm{kg}$ of body weight after treatment.

Blood sampling was carried out 3 times (before treatment, after treatment, and after induction). Blood was taken by direct withdrawal on the heart of mice that had been anesthetized with chloroform using a syringe. The blood is then taken to the clinical laboratory to check the levels of SGOT and SGPT. Data on the levels of SGOT and SGPT mice were analyzed by unidirectional analysis of variance using the Minitab program.

\section{RESULTS AND DISCUSSION}

In this study, data were obtained in the form of SGOT and SGPT activities in white rats' blood before treatment, after treatment, and after induction which can be seen in Tables 1 and 2.

The hepatotoxic levels of paracetamol in rats were assessed from the activity value of SGOT and SGPT after paracetamol administration of $2.5 \mathrm{~g}$ paracetamol per kg body weight and compared with those found after water treatment only [21]. In Tables 1 and 2, the activity of SGOT and SGPT after paracetamol administration was found to be higher than the group given distilled water. These results showed that the administration of paracetamol caused damage to rat liver cells.

SGOT and SGPT levels of paracetamol-induced rats which were pretreated with V. amygdalina leaf ethanolic extract with dose 50,100, and $200 \mathrm{mg}$ extract per kg body weight were found to be significantly lower than negative control group (paracetamol only).

The SGOT and SGPT levels in test group (with $V$. amygdalina leaf ethanolic extract) were decreasing with increasing of dose. From Tables 1 and 2, it can also be seen that the higher the pre-treatment dose of ethanol extract, the greater the inhibitory power of liver cells, which is characterized by the decreased levels of SGOT and SGPT in the blood of rats along with the increase in doses given [22]. The hepatoprotective activity shown by $V$. amygdalina leaf ethanolic extract may be caused by antioxidant activity in the plant [23].

The antioxidant activity occurs might be due to the presence of phenol and flavonoids in $V$. amygdalina. Flavonoids are thought to have an effect on inhibiting liver damage by binding to free radicals so that the impact on the liver decreases. In this study free radicals derived from paracetamol oxidation by the liver will cause integrity disruption hepatocyte membrane, causing the release of various enzymes from hepatocytes, including Serum Glutamic Oxaloacetic Transaminase (SGOT) and Serum Glutamic Pyruvic Transaminase (SGPT). Enzymes that come out of hepatocytes will increase in serum so that they can become indicators of liver damage [24]. The results of this study have shown that SGOT and SGPT levels of rats given with $V$. amygdalina leaf ethanolic extract then exposed to paracetamol were similar (not significantly different) with the group of rats that were not given the extract (normal control group) and with the group of rats that were given curcumin as the standard hepatoprotective compound (positive control group). Therefore, the administration of $V$. amygdalina leaf ethanolic extract was proven statistically by having hepatoprotective activity on the liver of male rats exposed to paracetamol.

\section{CONCLUSION}

Based on the data of SGPT and SGOT activity, it can be concluded that $V$. amygdalina leaf ethanolic extract has hepatoprotective properties against white rats induced by paracetamol. The higher the dose, the greater the hepatoprotective activity of liver cells.

\section{ACKNOWLEDGEMENT}

The authors acknowledge the laboratory support by Faculty of Pharmacy, University of Sumatera Utara, and Faculty of Mathematics and Natural Sciences, University of Sumatera Utara. 


\section{AUTHOR'S CONTRIBUTION}

All the authors have the same contribution in this research (carried out the research, collected the data, analyzed the data, and formatted the manuscript).

\section{CONFLICTS OF INTEREST}

The authors declare that they have no conflicts of interests in this research and this article.

\section{REFERENCES}

1. Yuan H, Ma Q, Ye L, Piao G. The traditional medicine and modern medicine from natural products. Molecules 2016;21:1-18.

2. Verma R. A review on hepatoprotective activity of medicinal plants. J Med Plants Stud 2018;6:188-90.

3. Huang ZQ, Chen P, Su WW, Wang YG, Wu H, Peng W, et al. Antioxidant activity and hepatoprotective potential of quercetin 7-rhamnoside in vitro and in vivo. Molecules 2018;23:1-13.

4. Ginting N, Suwarso E, Rumapea DV, Nerdy N. Relaxation activity of tetanus (Leea aequata L.) leaf ethanolic extract on Guinea pig isolated trachea. Asian J Pharm Clin Res 2018;11:1-4.

5. Haro G, Sinaga SM, Iksen I, Nerdy N, Theerachetmongkol S. Protective effect of chives leaves (Allioum schoenoprasum, L.) infusion against ethylene glycol and ammonium chloride induced nephrolithiasis in rats. J App Pharm Sci 2017; 7:222-5.

6. Putra ED, Ginting N, Nazliniwaty N, Iksen I, Kurniawan E, Nerdy N. In vitro antinephrolithiasis effect of breadfruit (Artocarpus altilis (park) fosberg) leaves extract by atomic absorption spectrophotometry. Asian J Pharm Clin Res 2018;11:1-4.

7. Karsono K, Patilaya P, Azisah N, Nerdy N. Comparison of antimicrobial activity of red betel (Piper crocatum Ruiz and Pav) leaves nanoparticle and powder ethanolic extract against methicillin resistant Staphylococcus aureus. Int J PharmTech Res 2015;8:696-701.

8. Masfria M, Haro G, Nerdy N, Mierza V, Wahyuni HS, Permata YM. Antimicrobials activity, antioxidants activity and analysis of active extract chemical compounds content of moringa (Moringa oleifera) leaf. Int J PharmTech Res 2016;9:110-20.

9. Nerdy N, Manurung K. Spectrophotometric method for antioxidant activity test and total phenolic determination of red dragon fruit leaves and white dragon fruit leaves. Rasayan J Chem 2018;11:1183-94.

10. Nazliniwaty N, Karsono K, Zebua NF, Nerdy N. Ethanol extract grapefruit peel (Citrus maxima Murr.) gel formulations with gelling agent durian seed gum and carboxy methyl cellulose. Pharm Chem 2016;8:207-13.

11. Nazliniwaty N, Karsono K, Zebua NF, Nerdy N. Antioxidant activity and antiaging gel formulation grapefruit peel (Citrus maxima Merr.) ethanolic extract. Pharm Lett 2016;8:84-94.

12. Nerdy N. In silico docking of chemical compounds from roselle calyces (Hibiscus sabdariffa L.) as antidiabetic. Int J ChemTech Res 2015;7:148-52.

13. Nerdy N. In silico docking roselle (Hibiscus sabdariffa L.) calyces flavonoids as antimalarial against plasmepsin 1 and plasmepsin 2. Asian J Pharm Clin Res 2017;10:183-6.

14. Nerdy N. In silico study of sesquiterpene lactone compounds from South Africa leaves (Vernonia amygdalina Del.) as antimalarial and anticancer. Int J PharmTech Res 2015;7:47-53.

15. Nerdy N, Putra ED, Haro G, Harahap U, Hutagaol R, Karsono K. In silico screening of hesperetin and naringenin ester derivatives as anticancer against p-glycoprotein. Int J Pharm Pharm Sci 2015;7:485-8.

16. Nerdy N, Putra ED, Haro G, Harahap U. In silico screening of hesperetin and naringenin ester derivatives as anticancer against phosphoinositide 3-kinase. Int J PharmTech Res 2016;9:388-94.

17. Tarigan MH, Harahap U, Dalimunthe A, Nerdy N. Antioxidant activity and cardioprotective activity of bangun-bangun leaves (plectranthus amboinicus lour.) ethanolic extract. Asian J Pharm Clin Res 2018;11:165-8.

18. Vasanthkumar T, Hanumanthappa M, Prabhakar BT, Hanumanthappa SK. Hepatoprotectiveeffectofcurcuminand capsaicinagainstlipopolysaccharide induced liver damage in mice. Pharmacog J 2017;9:947-51.

19. Alghazeer R, Elgahmasi S, Elnfati AH, Elhensheri M, Al-Griw MA, Awayn N, et al. Antioxidant activity and hepatoprotective potential of flavonoids from Arbutus pavarii against CCl4 induced hepatic damage. Biotech J Int 2018;21:1-12.

20. Manohar VR, Pai MR, Sabitha P, Paipushpalatha P, Rai M, Ullal SD. Hepatoprotective activity of Phyllanthus niruri in thioacetamide induced hepatotoxicity in male wistar rats. Int J Pharm Pharm Sci 2014;6:341-3.

21. Ramachandran A, Jaeschke H. Mechanisms of acetaminophen hepatotoxicity and their translation to the human pathophysiology. J Clin Transl Res 2017;3 S1:157-69.

22. Chiu YJ, Chou SC, Chiu CS, Kao CP, Wu KC, Chen CJ, et al. Hepatoprotective effect of the ethanol extract of Polygonum orientale on carbon tetrachloride induced acute liver injury in mice. J Food Drug Anal 2018;26:369-79.

23. Nchouwet ML, Ngnokam SL, Kodjio N, Poualeu SK, Nkengeffouet PA, Kamanyi A. Hepatoprotective and antioxidant effect of stem barks extracts methanolic and aqueous of Pseudocedrela kotschyi (Meliaceae) on paracetamol induced hepatic damage in rats. Asian J Biomed Pharm Sci 2017;7:1-9.

24. Ye H, Nelson LJ, del Moral MG, Martínez-Naves E, Cubero FJ. Dissecting the molecular pathophysiology of drug induced liver injury. World J Gastroenterol 2018;24:1373-85. 